\title{
Identifikasi Senyawa Kimia dalam Buah Kundur (Benincasa hispida (Thunb) Cogn.) dengan Kromatografi Gas-Spektrometer Massa (KG- SM)
}

\author{
Venty Suryanti*, Soerya Dewi Marliyana, Musmuallim Musmuallim \\ Prodi Kimia, Fakultas Matematika dan Ilmu Pengetahuan Alam, Universitas Sebelas Maret, Jl. Ir. Sutami \\ 36 , Surakarta 57126 \\ *Corresponding author \\ E-mail: venty@mipa.uns.ac.id
}

DOI: 10.20961/alchemy.14.1.13496.84-94

Received 25 August 2017, Accepted 4 December 2017, Published 1 March 2018

\begin{abstract}
ABSTRAK
Telah dilakukan isolasi dan identifikasi senyawa kimia buah kundur (Benincasa hispida). Komponen non polar dipisahkan dengan metode ekstraksi soxhlet selama 24 jam menggunakan pelarut petroleum eter. Residu dari ekstraksi soxhlet selanjutnya dimaserasi selama 24 jam menggunakan pelarut etanol. Terhadap ekstrak etanol selanjutnya dilakukan pemisahan senyawa kimia dengan kromatografi kolom menggunakan pelarut heksana, campuran heksana dengan etanol dan etanol. Fraksi yang telah terisolasi diidentifikasi dengan Kromatografi Gas-Spektrometer Massa (KG-SM). Senyawa yang berhasil teridentifikasi adalah tridekananitril, pentadekananitril dan heptadekananitril.
\end{abstract}

Kata kunci: Benincasa hispida, buah kundur, identifikasi, isolasi.

\begin{abstract}
Identification of Chemical Constituents of Kundur Fruit (Benincasa Hispida (Thunb) Cogn.) by Gas Chromatography-Mass Spectrometry (GC-MS). Isolation and identification of chemical compounds of the kundur fruit (Benincasa hispida) have been conducted. Non polar components were isolated by soxhlet extraction for $24 \mathrm{~h}$ using petroleum ether as solvent. The residu was extracted by maseration using ethanol for $24 \mathrm{~h}$. To the ethanol extract was applied chromatography column for further isolation using hexane, mixtures of hexane-ethanol, and ethanol as eluents. The isolated compounds were then identified by Gas Chromatography-Mass Spectrometry (GC-MS). The identified compounds were tridecanenitrile, pentadecanenitrile and heptadecanenitrile.
\end{abstract}

Keywords: Benincasa hispida, identification, isolation, kundur fruit.

\section{PENDAHULUAN}

Indonesia memiliki keanekaragaman flora dan telah dikenal sebagai negara dengan sumber alam hayati terbesar kedua setelah Brasil. Kekayaan sumber alam hayati ini belum dimanfaatkan secara optimal. Sebagian besar pemanfaatan tanaman tersebut masih dalam skala kecil untuk pemeliharaan kesehatan dan pengobatan penyakit secara tradisional 
berdasarkan pengetahuan turun-temurun. Pengembangan sumber daya hayati yang belum optimal membuka peluang terjadinya pengambilan tanaman dan pengetahuan lokal untuk pemanfaatan tanaman obat oleh pihak luar.

Salah satu ragam tanaman yang banyak terdapat di Indonesia adalah famili Cucurbitaceae. Famili ini mencakup kira-kira 960 spesies yang terbagi dalam 125 marga. Famili Cucurbitaceae atau suku labu-labuan merupakan tumbuhan berbunga dan umumnya merupakan tanaman yang menjalar. Suku Cucurbitaceae telah dikenal sebagai sumber metabolit sekunder (Ng, 1993). Senyawa cucurbitacins, suatu triterpenoid tetrasiklik yang memberi rasa pahit pada banyak spesies dari cucurbitaceae, telah dipelajari sebagai penarik kumbang (Whitaker and Davis, 1962). Alkaloid telah dilaporkan terdapat dalam Momordica, dan saponin telah ditemukan dalam Cucurbita, Citrullus, Lagenaria dan Momordica (Schultes, 1990).

Salah satu jenis tanaman Cucurbitaceae adalah buah kundur (Benincasa hispida). Buah kundur telah dimanfaatkan sebagai sayuran dan obat tradisional. Buah kundur dimanfaatkan sebagai obat pembersih usus dan penyembuh penyakit fisik seperti penyakit kulit dan demam. Buah kundur juga telah digunakan untuk menyembuhkan epilepsi, gonore (kencing nanah) dan infeksi organisme seperti membersihkan cacing dalam usus (Ng, 1993). Beberapa kegunaan buah kundur dalam pengobatan juga telah dilaporkan (Abdullah et al., 2012; Al-Snafi, 2013; Mandana et al., 2012; Meghashree et al., 2017; Nimbal et al., 2011; Rana and Suttee, 2012; Vijayabhaskar and Paramesh, 2015).

Pemanfaatan buah kundur telah banyak diketahui namun pengetahuan tentang kandungan kimia yang sudah dipelajari pada buah kundur masih sangat terbatas. Buah kundur mengandung protein, lemak, karbohidrat, mineral, thiamin, riboflavin (Cantwell et al., 1996). Sheemole et al. (2016) melaporkan komponen buah kundur hasil analisa dengan menggunakan LC-MS, sedangkan Une and Doshi (2014) melaporkan senyawa kimia ekstrak biji buah kundur hasil analisa dengan menggunakan HPLC dan HPTLC. Buah kundur sebagai salah satu jenis Cucurbitaceae merupakan salah satu sumber metabolit sekunder. Oleh karena itu, penelitian ini bertujuan untuk mengisolasi dan mengidentifikasi komponen kimia yang terdapat dalam buah kundur. Jika komponen kimia buah kundur dapat diketahui dengan jelas, maka pemanfaatannya dapat dilakukan secara optimal. Dalam penelitian ini identifikasi dilakukan dengan menggunakan Kromatografi GasSpektrometer Massa (KG-SM) pada komponen-komponen yang terdapat dalam ekstrak etanol buah kundur. 


\section{METODE PENELITIAN}

Buah kundur yang digunakan dalam penelitian ini berasal dari daerah Kabupaten Sragen. Hasil determinasi yang dilakukan di Laboratorium Taksonomi Tumbuhan Fakultas Biologi Universitas Gadjah Mada, Yogyakarta menyatakan bahwa buah kundur yang digunakan berasal dari Familia Cucurbitaceae, Genus Benincasa dengan species Benincasa hispida (Thumb.) Cogn. Bahan lain yang digunakan dalam penelitian ini berasal dari $E$ merck yaitu petroleum eter, etanol, heksana dan silika gel 60 dan silika gel $\mathrm{G}_{254}$.

Alat yang digunakan dalam penelitian ini adalah satu set alat soxhlet, satu set alat destilasi, satu set alat kromatografi kolom, oven, rotary evaporator Buchi B-720, GC-MS Shimadzu QP-5000 dan lampu UV 254 dan UV 365 nm.

\section{Pembuatan Simplisia Buah Kundur}

Buah kundur dicuci, dikupas kulitnya, dibuang bijinya, dipotong tipis-tipis kemudian dikeringkan dengan oven pada suhu $100{ }^{\circ} \mathrm{C}$ selama 3-4 jam. Buah kundur kering di blender sampai berbentuk serbuk.

\section{Pembuatan Ekstrak Etanol Buah Kundur}

Sebanyak 35 g serbuk buah kundur diekstraksi soxhlet menggunakan $350 \mathrm{~mL}$ petroleum eter selama 24 jam. Residu hasil ekstraksi soxhlet dikeringkan dan kemudian dimaserasi dalam etanol $150 \mathrm{~mL}$ selama 24 jam. Penyaringan dengan buchner dilakukan untuk mengambil filtratnya yaitu untuk memisahkan ekstrak etanol dari ampasnya. Langkah-langkah ini diulangi sebanyak 3 kali. Filtrat yang terkumpul dipekatkan dengan rotary evaporator.

\section{Pembuatan Fraksi Buah Kundur}

Ekstrak etanol sebanyak 1,5 mL dimasukkan ke dalam kolom yang berdiameter $1,5 \mathrm{~cm}$, panjang $50 \mathrm{~cm}$ dan terisi $30 \mathrm{~g}$ silika gel 60 . Elusi dilakukan menggunakan pelarut $100 \mathrm{~mL}$ dengan kepolaran yang semakin meningkat dengan perbandingan v/v untuk nheksana:etanol berturut-turut adalah $10: 0 ; 7,5: 2,5 ; 1: 1 ; 1: 3$ dan $0: 10$. Eluat ditampung setiap $2 \mathrm{~mL}$ dalam tabung reaksi dan diuapkan pelarutnya. Kemudian ditentukan fraksi-fraksinya dan dilakukan uji dengan KG-SM.

\section{Identifikasi Senyawa Kimia Fraksi Buah Kundur dengan Kromatografi Gas- Spektrometer Massa (KG-SM)}

Kondisi operasi KG-MS saat analisis sampel buah kundur adalah jenis pengionan: EI (Electron Impack) $70 \mathrm{EV}$; jenis kolom : CD sil $5 \mathrm{CB}$; panjang kolom : $25 \mathrm{~m}$; suhu kolom: 
80-250 ${ }^{\circ} \mathrm{C}$; gas pembawa : He $10 \mathrm{KPa}$; suhu detektor: $260{ }^{\circ} \mathrm{C}$; suhu injektor: $260{ }^{\circ} \mathrm{C}$ dan kecepatan kenaikan suhu: $10{ }^{\circ} \mathrm{C} /$ menit.

\section{PEMBAHASAN}

\section{Pembuatan Sampel}

Buah kundur sebanyak $7 \mathrm{~kg}$ menghasilkan $150 \mathrm{~g}$ serbuk kering berwarna putih. Hasil ekstraksi soxhlet $35 \mathrm{~g}$ serbuk kundur dengan $350 \mathrm{~mL}$ petroleum eter menghasilkan ekstrak encer berwarna kuning kehijauan sebanyak $255 \mathrm{~mL}$. Residu dari ekstraksi soxhlet kemudian dimaserasi dengan etanol menghasilkan ekstrak etanol pekat berbentuk cairan yang berwarna coklat kehitaman sebanyak $15 \mathrm{~mL}$. Eluat hasil kromatografi kolom dikelompokkan menjadi tiga fraksi. Pada Fraksi I terdapat endapan berwarna kuning dengan bau seperti rempah-rempah. Fraksi II berwarna kuning kecoklatan dan bau yang menyengat. Fraksi III terdapat cairan berwarna kuning kecoklatan dengan bau yang kurang tajam.

\section{Analisis Kromatografi Gas-Spektrometer Massa (KG-SM)}

Kromatogram hasil analisis KG-SM dari fraksi I menunjukkan 8 puncak yang terpisahkan (Gambar 1). Kromatogram hasil KG-SM untuk fraksi II dan III tidak menunjukkan adanya puncak yang menonjol. Senyawa-senyawa yang termasuk dalam golongan tanin, saponin dan antrakuinon diperkirakan berada pada fraksi II dan III yang tidak terdeteksi dengan KG-SM karena titik didihnya lebih tinggi dari $300{ }^{\circ} \mathrm{C}$.

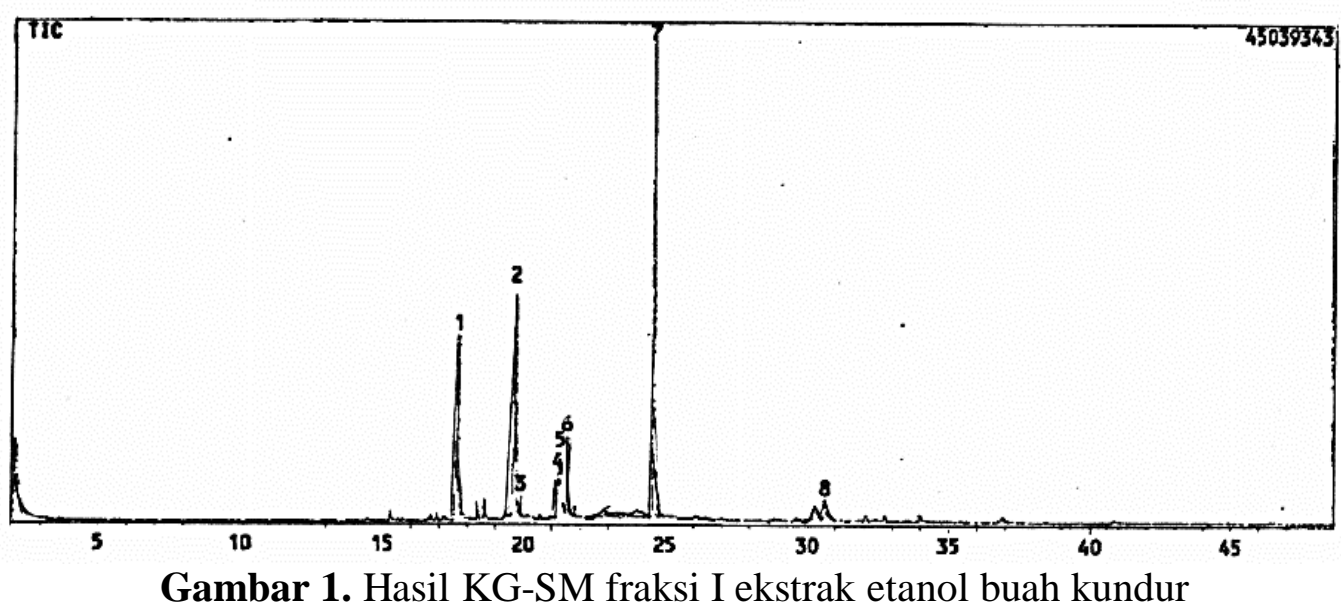

Analisis spektrofotometer massa dilakukan terhadap 5 puncak yang tertinggi dari 8 puncak yang dihasilkan dari pemisahan KG-SM fraksi I (Gambar 1). Analisis senyawa pertama dilakukan terhadap puncak-puncak berdasarkan fragmentasi tiap-tiap senyawa dibandingkan dengan spektra massa standar yang ada pada library alat NIST12, NIST62, dan WILEY229, tetapi karena indeks kesamaan atau similarity indeks (SI) yang rendah 
maka spektra massa standar dari library alat NIST12, NIST62, dan WILEY229 tidak dapat digunakan. Data pendukung lain dicari melalui penelusuran spektra-spektra massa dari data sekunder hasil penelitian yang ada, tetapi karena penelusuran melalui data sekunder juga belum ditemukan maka analisis lebih lanjut dilakukan dengan studi literatur terhadap pola fragmentasi. Studi literatur terhadap pola fragmentasi ditekankan pada penelusuran base peak (puncak dasar) dan puncak-puncak yang khas dari suatu senyawa kemudian dibandingkan dengan spektra massa dari senyawa yang akan ditentukan.

\section{Puncak 1 (Senyawa a)}

Spektra massa senyawa $\boldsymbol{a}$ dengan waktu retensi 17,692 menit dan fragmentasi senyawa a dapat dilihat pada Gambar 2. Senyawa $\boldsymbol{a}$ diperkirakan mempunyai ion molekul massa dengan $\mathrm{m} / \mathrm{z}$ 195. Senyawa ini diduga merupakan suatu senyawa nitril alifatik. Hal ini ditunjukkan oleh adanya puncak dasar yang terdapat pada $\mathrm{m} / \mathrm{z} 41$ yang merupakan puncak dasar senyawa nitril alifatik. Puncak ini berasal dari $\left[\mathrm{CH}_{2} \mathrm{CNH}\right]^{+}$. Dugaan ini juga diperkuat dengan adanya puncak pada m/z 97 pada spektra massa senyawa $\boldsymbol{a}$ yang merupakan puncak khas senyawa nitril alifatik (Silverstein, 1986). Selain itu puncak ion molekul pada m/z 195 yang bernilai ganjil menunjukkan bahwa senyawa tersebut mengandung atom nitrogen yang jumlahnya ganjil. Puncak pada m/z 97 berasal dari $\left[\left(\mathrm{CH}_{2}\right)_{5} \mathrm{CNH}\right]^{+}$. Fragmen pada $\mathrm{m} / \mathrm{z} 83$ adalah $\left[\mathrm{CH}_{3}\left(\mathrm{CH}_{2}\right)_{3} \mathrm{CN}\right]^{+}$dan fragmen pada $\mathrm{m} / \mathrm{z} 55$ adalah $\left[\mathrm{CH}_{3} \mathrm{CH}_{2} \mathrm{CN}\right]^{+}$. Senyawa $\boldsymbol{a}$ diperkirakan adalah tridekananitril. Perkiraan fragmentasi tridekananitril ditujukkan pada Gambar 3.

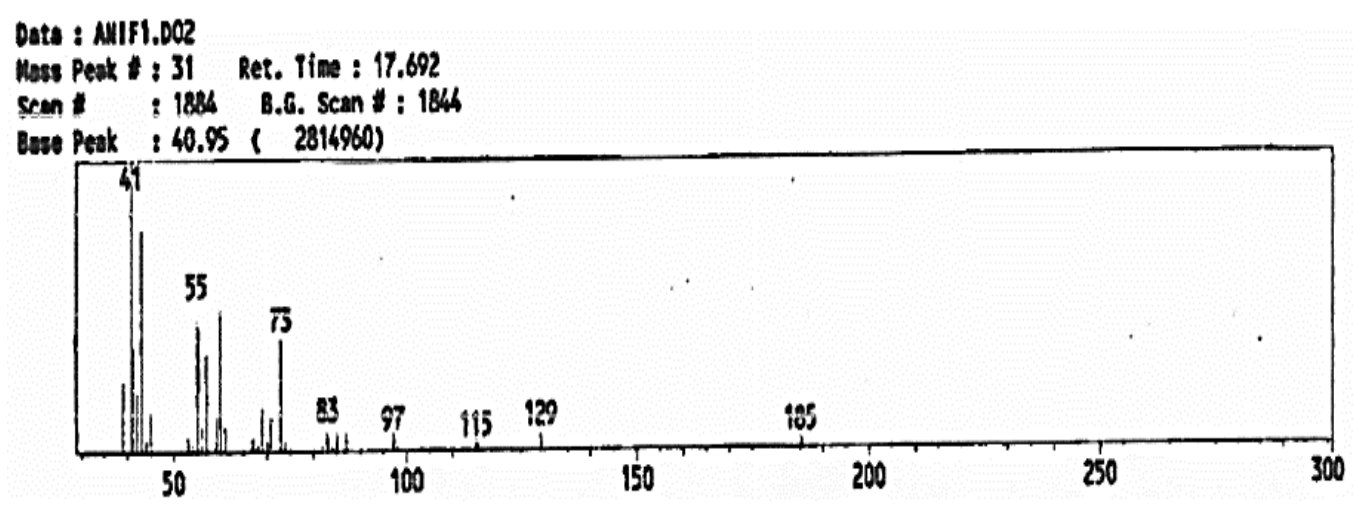

Gambar 2. Spektra massa senyawa $\boldsymbol{a}$

\section{Puncak 2 (Senyawa b)}

Spektra massa senyawa $\boldsymbol{b}$ dengan waktu retensi 19,742 dan fragmentasinya dapat dilihat pada Gambar 4 dan Tabel 1. Senyawa $\boldsymbol{b}$ diperkirakan mempunyai ion molekul massa dengan $\mathrm{m} / \mathrm{z} 223$. Senyawa ini diduga merupakan suatu senyawa nitril alifatik. Hal ini ditunjukkan oleh adanya puncak dasar yang terdapat pada m/z 41 yang merupakan 
puncak dasar senyawa nitril alifatik. Puncak dasar ini berasal dari $\left[\mathrm{CH}_{2} \mathrm{CNH}\right]^{+}$. Dugaan ini juga diperkuat dengan adanya puncak pada m/z 97 pada spektra massa senyawa $\boldsymbol{b}$ yang merupakan puncak khas senyawa nitril alifatik (Silverstein, 1986). Selain itu puncak ion molekul pada m/z 223 yang bernilai ganjil menunjukkan bahwa senyawa tersebut mengandung atom nitrogen yang jumlahnya ganjil. Puncak pada m/z 97 berasal dari $\left[\left(\mathrm{CH}_{2}\right)_{5} \mathrm{CNH}\right]^{+}$. Fragmen pada $\mathrm{m} / \mathrm{z} 83$ adalah $\left[\mathrm{CH}_{3}\left(\mathrm{CH}_{2}\right)_{3} \mathrm{CN}\right]^{+}$dan fragmen pada $\mathrm{m} / \mathrm{z} 55$ adalah $\left[\mathrm{CH}_{3} \mathrm{CH}_{2} \mathrm{CN}\right]^{+}$. Senyawa $\boldsymbol{b}$ diperkirakan adalah pentadekananitril. Perkiraan fragmentasi pentadekananitril ditujukkan pada Gambar 5.

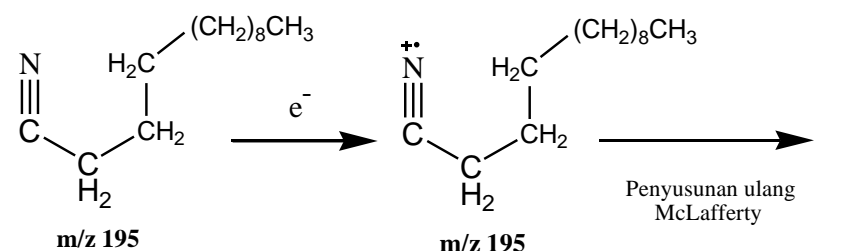<smiles>CCC1CC2CCC(C2)C1CC</smiles>

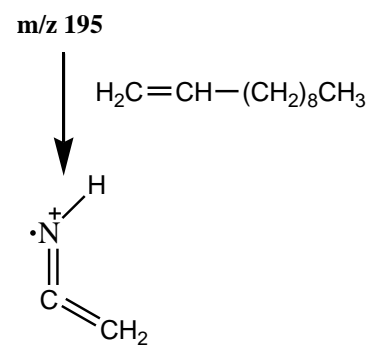
$\mathbf{m} / \mathbf{z} 41$<smiles>CCCCCCCCC=N</smiles>

$\mathbf{m} / \mathbf{z} 195$

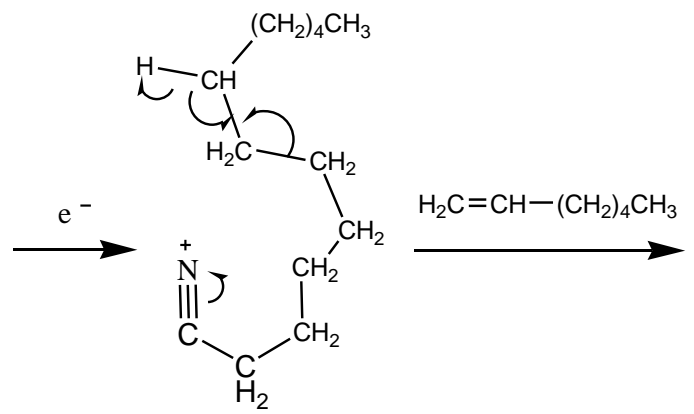

$\mathbf{m} / \mathbf{z} 195$<smiles>C1=NC2CCCCCC1CCC2</smiles>

$\mathbf{m} / \mathbf{z} 97$

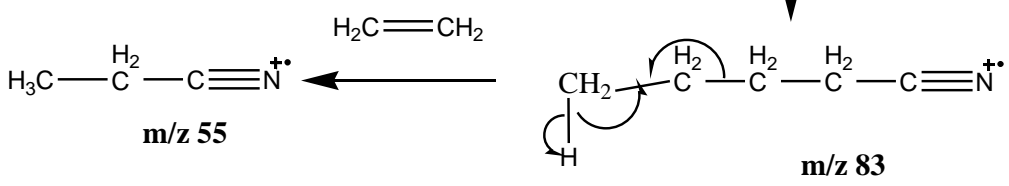

Gambar 3. Perkiraan mekanisme fragmentasi senyawa tridekananitril 


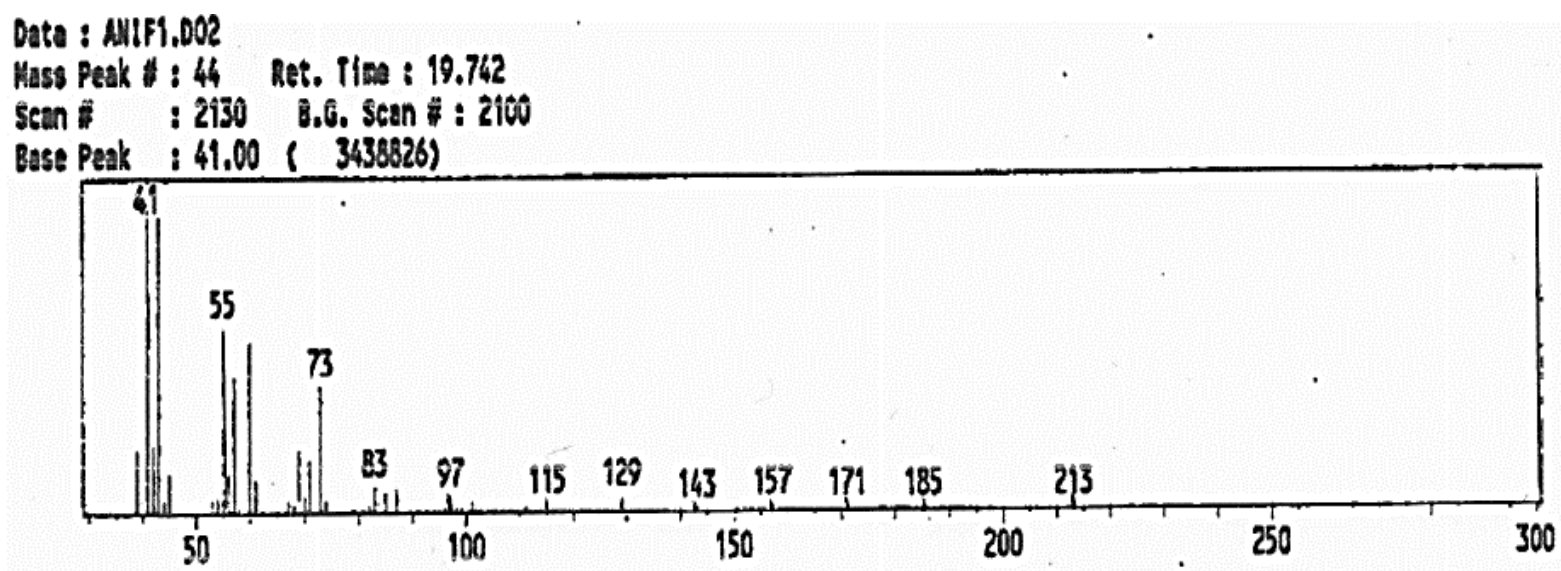

Gambar 4. Spektra massa senyawa $b$

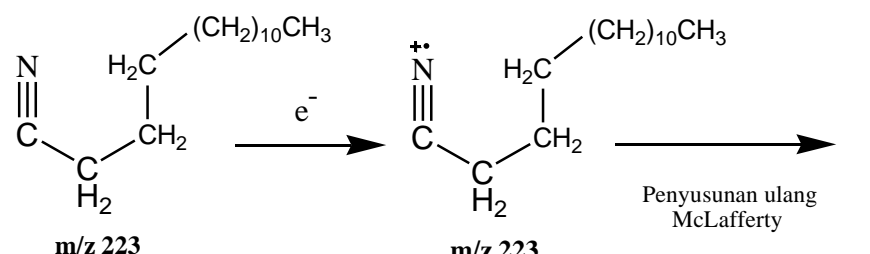

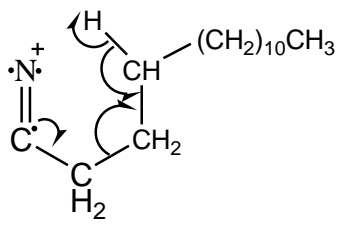

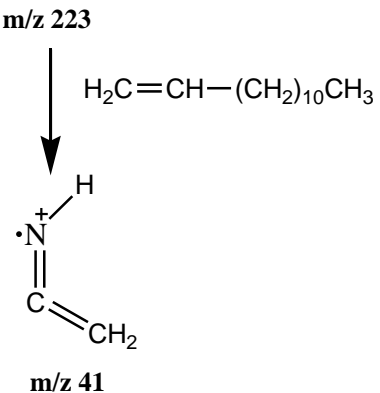

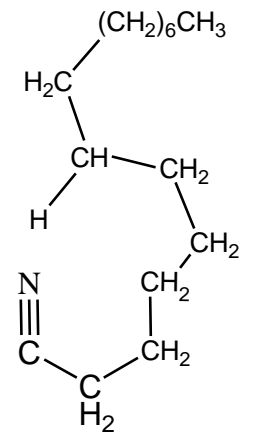

$\mathbf{m} / \mathbf{z} 223$
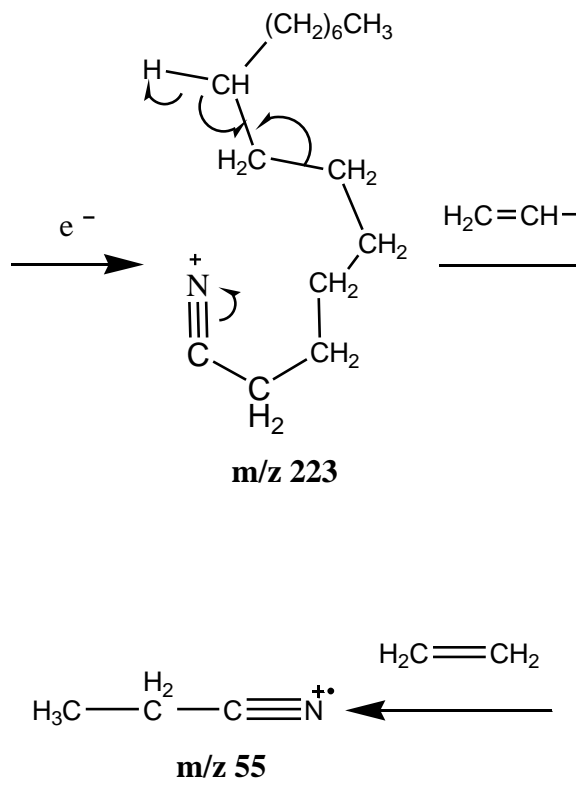

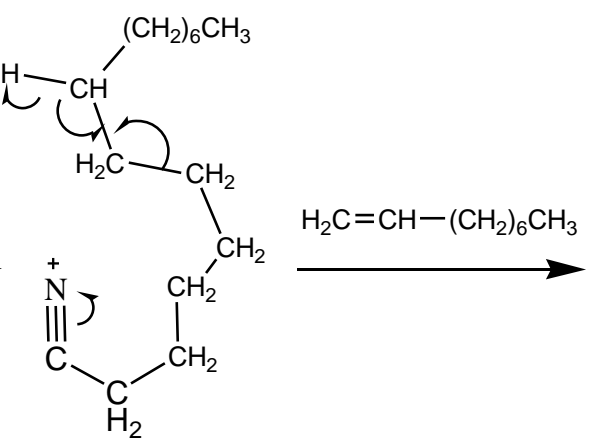

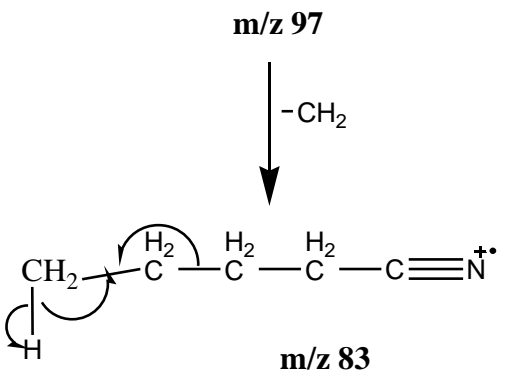

Gambar 5. Perkiraan mekanime fragmentasi senyawa pentadekananitril

Tabel 1. Data $\mathrm{m} / \mathrm{z}$ senyawa yang teridentifikasi dari fraksi I ekstrak etanol buah kundur 


\begin{tabular}{|c|c|c|c|c|c|c|}
\hline No. & $\begin{array}{l}\text { Waktu retensi } \\
\text { (menit) }\end{array}$ & Senyawa & $\begin{array}{c}\text { Berat } \\
\text { Molekul }\end{array}$ & Fragmentasi & $\begin{array}{c}\text { Perkiraan } \\
\text { Senyawa }\end{array}$ & SI** \\
\hline 1. & 17,692 & $\begin{array}{l}\text { Senyawa } \boldsymbol{a} \\
\text { (puncak 1) }\end{array}$ & 195 & $\begin{array}{c}41^{*}, 55,73,83,97 \\
115,129,185,195\end{array}$ & Tridekananitril & 86 \\
\hline 2. & 19,742 & $\begin{array}{l}\text { Senyawa } \boldsymbol{b} \\
\text { (puncak 2) }\end{array}$ & 223 & $\begin{array}{l}41^{*}, 55,73,83,97 \\
115,129,143,157 \\
171,185,213,223\end{array}$ & Pentadekananitril & 89 \\
\hline 3. & 21,317 & $\begin{array}{l}\text { Senyawa } c \\
\text { (puncak 5) }\end{array}$ & 268 & $\begin{array}{c}41^{*}, 55,67,81,96 \\
111,135,171,185 \\
194,234,268\end{array}$ & - & - \\
\hline 4. & 21,567 & $\begin{array}{l}\text { Senyawa } d \\
\text { (puncak 6) }\end{array}$ & 251 & $\begin{array}{c}41 *, 55,73,83,97 \\
111,129,143,152 \\
185,241,251\end{array}$ & Heptadekananitril & 91 \\
\hline 5. & 24,625 & $\begin{array}{l}\text { Senyawa } \boldsymbol{e} \\
\text { (puncak 7) }\end{array}$ & 279 & $\begin{array}{c}41 *, 57,71,83,104 \\
132,149,167,279\end{array}$ & - & - \\
\hline
\end{tabular}

* = base peak/puncak dasar

** SI = similarity index

\section{Puncak 5 (Senyawa $c)$}

Senyawa $\boldsymbol{c}$ mempunyai waktu retensi 21,317 dan fragmentasi senyawa $\boldsymbol{c}$ dapat dilihat pada Gambar 6 dan Tabel 1. Puncak dasar terdapat pada m/z 41. Puncak paling kanan pada spektra massa terdapat pada $\mathrm{m} / \mathrm{z}$ 268. Pola fragmentasi senyawa $\boldsymbol{c}$ belum dapat dianalisis karena data pendukung dan sekunder belum ditemukan. Sehingga analisis lebih lanjut terhadap spektra massa senyawa ini tidak dilakukan.

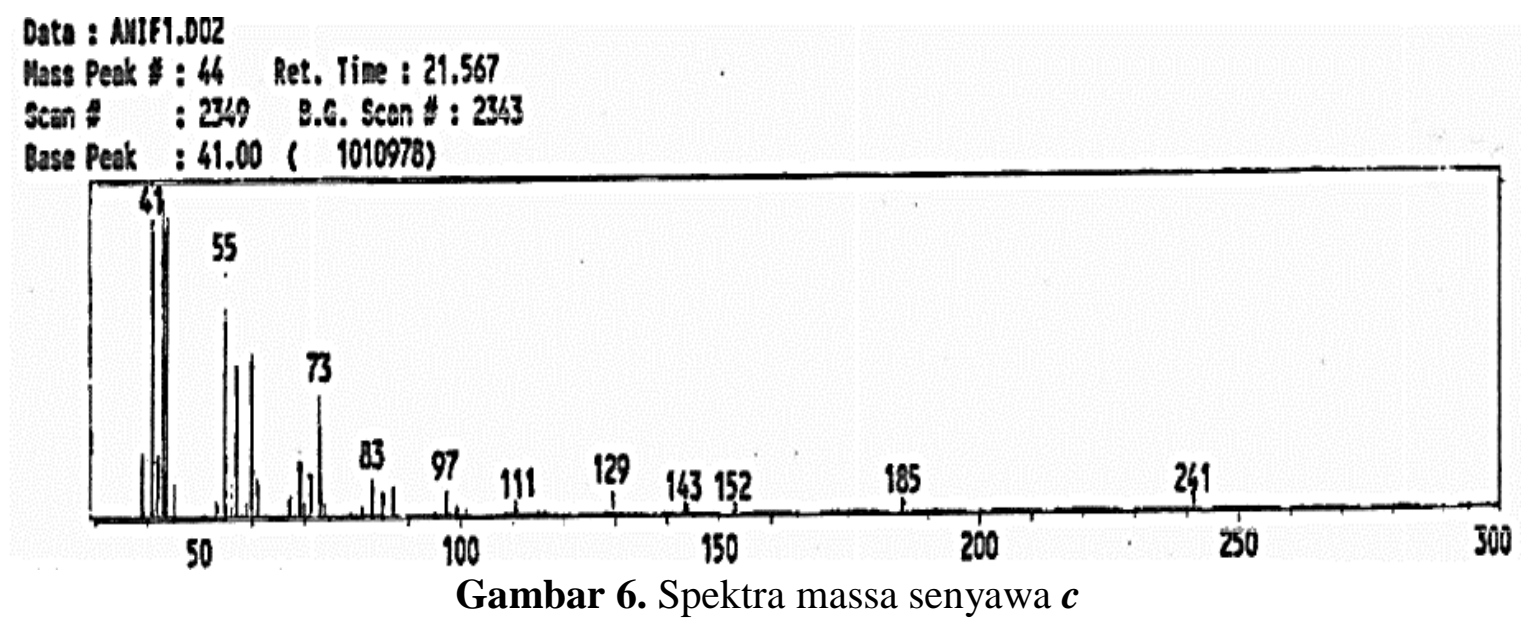

\section{Puncak 6 (Senyawa $d$ )}

Spektra massa senyawa $\boldsymbol{d}$ dengan waktu retensi 21,567 dan fragmentasinya dapat dilihat pada Gambar 7 dan Tabel 1. Senyawa $\boldsymbol{d}$ diperkirakan mempunyai ion molekul massa dengan $\mathrm{m} / \mathrm{z} 251$. Senyawa $\boldsymbol{d}$ diduga merupakan suatu senyawa nitril alifatik. Hal ini ditunjukkan oleh adanya puncak dasar yang terdapat pada m/z 41 yang merupakan puncak dasar senyawa nitril alifatik. Puncak dasar ini berasal dari $\left[\mathrm{CH}_{2} \mathrm{CNH}\right]^{+}$. Dugaan ini diperkuat juga dengan adanya puncak pada m/z 97 pada spektra massa senyawa $\boldsymbol{d}$ yang merupakan puncak khas senyawa nitril alifatik (Silverstein, 1986). Selain itu puncak ion 
molekul pada m/z 251 yang bernilai ganjil menunjukkan bahwa senyawa tersebut mengandung atom nitrogen yang jumlahnya ganjil.

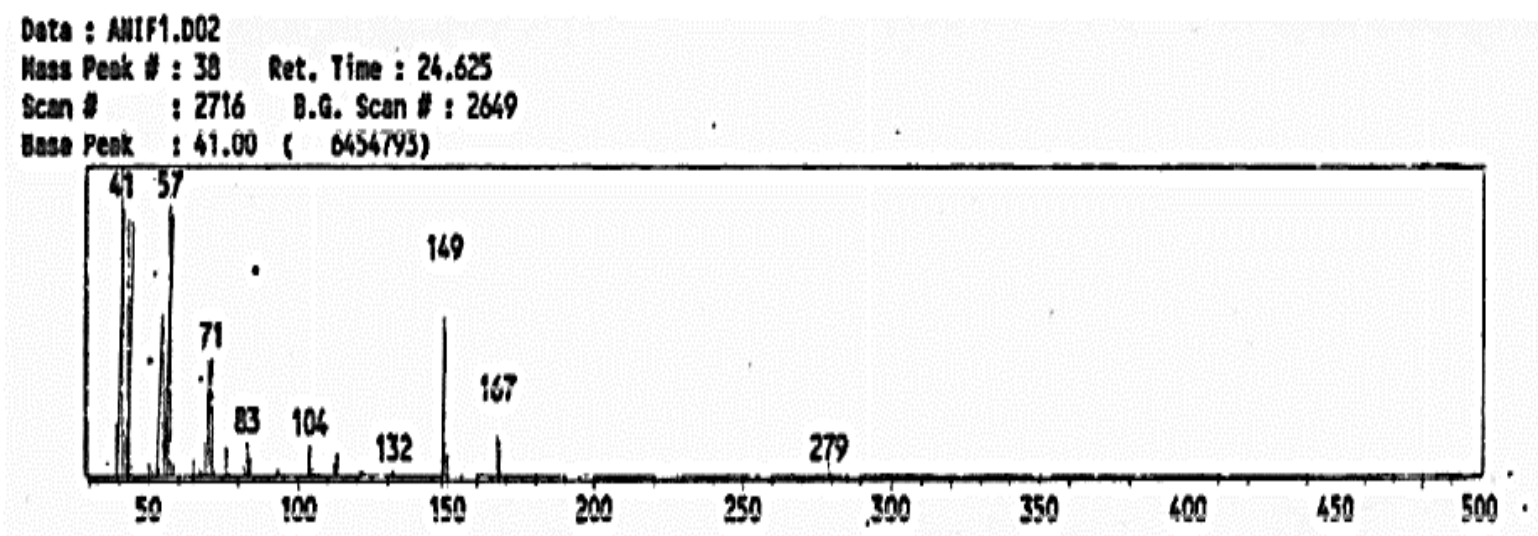

Gambar 7. Spektra massa senyawa $d$

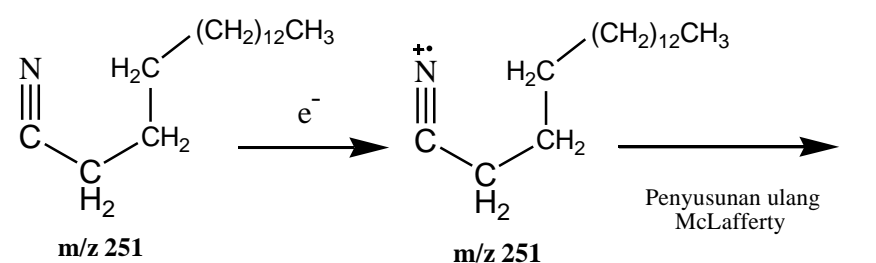<smiles>CCCC1CC2CCC(C2)C1CC</smiles>

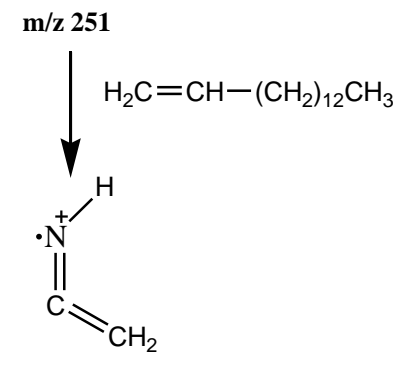<smiles>CCCCCCCCC=N</smiles>

$\mathbf{m} / \mathbf{z} 251$
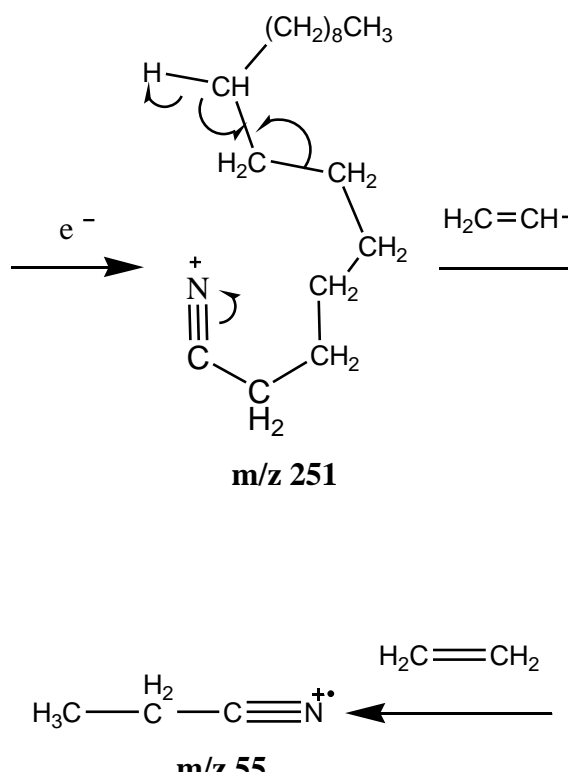

$\mathbf{m} / \mathbf{z} 251$<smiles>C=CCCCCCCCCCCCCCCCCCC</smiles>

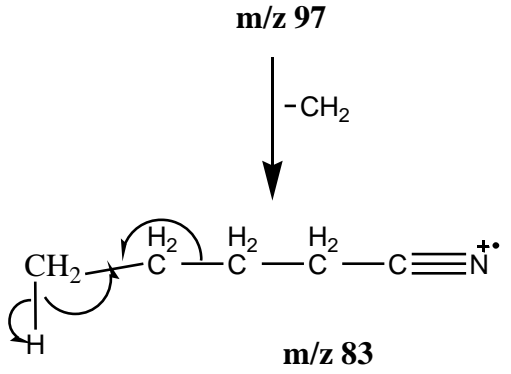

Gambar 8. Perkiraan mekanisme fragmentasi senyawa heptadekananitril 
Puncak pada m/z 97 berasal dari $\left[\left(\mathrm{CH}_{2}\right)_{5} \mathrm{CNH}\right]^{+}$. Fragmen pada $\mathrm{m} / \mathrm{z} 83$ adalah $\left[\mathrm{CH}_{3}\left(\mathrm{CH}_{2}\right)_{3} \mathrm{CN}\right]^{+}$dan fragmen pada m/z 55 adalah $\left[\mathrm{CH}_{3} \mathrm{CH}_{2} \mathrm{CN}\right]^{+}$. Senyawa $\boldsymbol{d}$ diperkirakan adalah heptadekananitril. Perkiraan fragmentasi heptadekananitril ditujukkan pada Gambar 8.

\section{Puncak 7 (Senyawa $e$ )}

Senyawa e mempunyai waktu retensi 24,625 dan fragmentasi senyawa e dapat dilihat pada Gambar 9 dan Tabel 1. Puncak dasar (base peak) terdapat pada m/z 41 . Puncak paling kanan pada spektra massa terdapat pada $\mathrm{m} / \mathrm{z} 279$. Pola fragmentasi senyawa $\boldsymbol{e}$ belum dapat dianalisis karena data pendukung dan sekunder belum ditemukan, sehingga analisis lebih lanjut terhadap spektra massa senyawa ini tidak dilakukan.

Keseluruhan senyawa yang muncul pada spektra hasil KG-SM dari fraksi I ekstrak etanol buah kundur ditunjukkan oleh Tabel 1. Senyawa yang sudah dapat dianalisa adalah tridekananitril, pentadekananitril, dan heptadekananitril. Dua senyawa yang lain belum dapat dianalisa yaitu senyawa yang muncul pada waktu retensi 19,742 dan 24,625 menit.

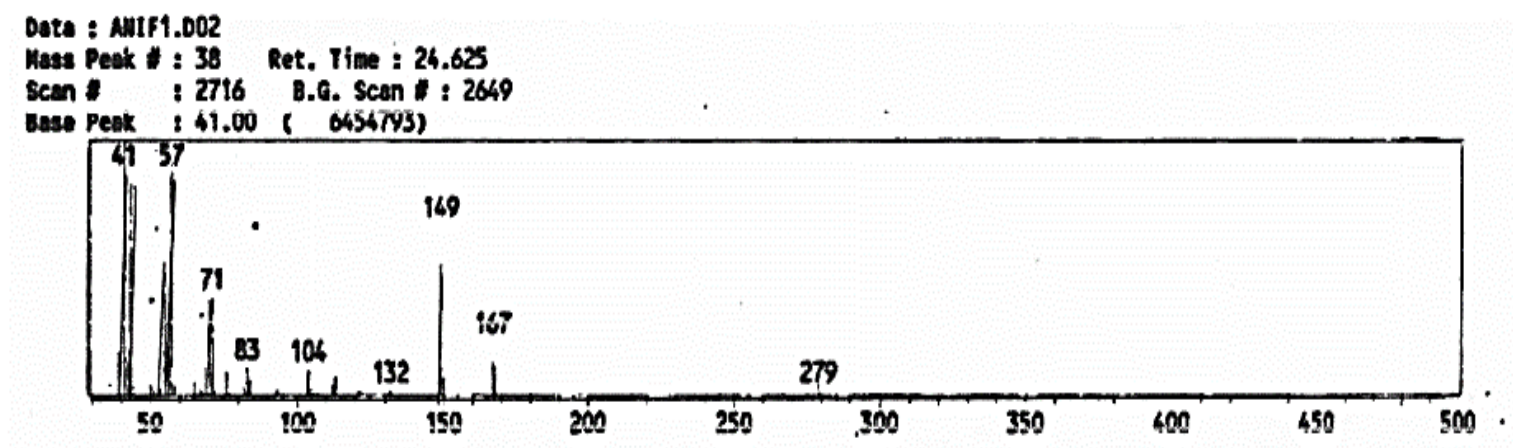

Gambar 9. Spektra massa senyawa $\boldsymbol{e}$

\section{KESIMPULAN}

Isolasi komponen kimia buah kundur dalam pelarut etanol yang dilakukan dengan cara maserasi menghasilkan ekstrak etanol pekat berbentuk cairan berwarna coklat kehitaman. Isolasi dengan kromatografi kolom menghasilkan 3 fraksi, yaitu fraksi I berbentuk padatan berwarna kuning dengan bau mirip rempah-rempah, fraksi II berbentuk padatan berwarna kuning kecoklatan dengan bau menyengat dan fraksi III berbentuk cairan dengan bau yang kurang tajam. Analisis spektra KG-SM pada fraksi I menunjukkan senyawa-senyawa yang teridentifikasi diperkirakan adalah tridekananitril, pentadekananitril, dan heptadekananitril. Fraksi II dan fraksi III tidak menghasilkan puncak pada kromatogram hasil analisa dengan KG-SM. 


\section{DAFTAR PUSTAKA}

Abdullah, U., Kamarudin, W.S.S.W., Samicho, Z., Aziman, N., and Zulkifli, K.S., 2012. Evaluation of in-vitro antioxidant and antimicrobial activities of the various parts of Benincasa hispida. International Journal of PharmTech Research 4(4), 1367-1376.

Al-Snafi, A.E., 2013. The pharmacological importance of Benincasa hispida. A review. International Journal of Pharma Sciences and Research 4(12), 165-170.

Cantwell, M., Nie, X., Zong, R.J., and Yamaguchi, M., 1996. Asian Vegetables : Selected Fruit and Leafy Types. in : J. Janick (ed), Progress in New Crops. ASHS Press. Arlinton, VA. pp. 488-495.

Mandana, B., Russly, A.R., Farah, S.T., Noranizan, M.A., Zaidul, I.S. and Ali, G., 2012. Antioxidant activity of winter melon (Benincasa Hispida) seeds using conventional soxhlet extraction technique, International Food Research Journal 19(1), 229-234.

Meghashree, B.M., Shantha, T.R., Venkateshwarlu, G., and Bhat, S., 2017. Comparative pharmacognostical and histochemical studies on Benincasa Hispida (Thunb.) Cogn.- Fruit and Seed. International Journal of Herbal Medicine 5(4), 17-24.

Nimbal, S.K., Venkatrao, N., Pujar, B., and Ladde, S., 2011. Evaluation of anticonvulsant activity of alcoholic extract of Benincasa Hispida (Thunb) cogn. fruit extracts. International Research Journal of Pharmacy 2(12), 166-168.

Ng, T.J., 1993. New opportunities in the Cucurbitaceae. In : J.Janick and J.E.Simon (eds.). New crops. Wiley. New York. pp. 538-546.

Rana, S., and Suttee, A., 2012. Phytochemical investigation and evaluation of free radical scavenging potential of Benincasa hispida peel extracts. International Journal of Current Pharmaceutical Review and Research 3(3), 43-46.

Schultes, R.E., 1990. Biodynamic cucurbits in the New World tropics, In: D.M. Bates, R.W. Robinson, and C. Jeffrey (eds.). Biology and utilization of the Cucurbitaceae. Cornell Univ. Press, Ithaca, NY. pp. 307-317.

Sheemole, M.S., Antony, V.T., Kala, K., and Saji, A., 2016, Phytochemical analysis of Benincasa hispida (Thunb.) cogn. fruit using LC-MS technique, International Journal of Pharmaceutical Sicences Review and Research 36(1), 244-248.

Silverstein, R. M. 1986. Penyidikan Spektrometrik Senyawa Organik. Terjemahan A. J. Hatomo dan Anny Viktor Purba. Edisi keempat, Penerbit Erlangga. Jakarta

Une, H.D., and Doshi, G.M., 2014. Chromatographic studies on Benincasa hispida (thunb.) cogn. seed extract scrutinized by HPLC and HPTLC. Pharmacognosy Journal 6(2), 42-48, doi: 10.5530/pj.2014.3.7

Vijayabhaskar, K., and Paramesh, P., 2015. Evaluation of antihistaminic activity of Benincasa Hispida flower aqueous extract for histamine aerosol induces Bronchoconstriction in guinea pig. World Journal of Pharmacy and Pharmaceutical Sciences 4(7), 751-760.

Whitaker, T.W. 1990. Cucurbits of potential economic importance. In: D.M. Bates, R.W. Robinson, and C. Jeffrey (eds.) Biology and utilization of the Cucurbitaceae. Cornell Univ. Press, Ithaca. pp. 318-324. 